\title{
EFFECT OF MERALLURIDE ON SOLUTE AND WATER EXCRETION IN HYDRATED MAN : COMMENTS ON SITE OF ACTION*
}

\author{
By MARVIN H. GOLDSTEIN, $\dagger$ MARVIN F. LEVITT, A. DANIEL HAUSER $\dagger$ AND \\ DEMETRA POLIMEROS
}

(From the Division of Renal Diseases, Department of Medicine, The Mount Sinai Hospital, N. Y.)

(Submitted for publication July 18, 1960 ; accepted December 19, 1960)

The renal tubular site at which organomercurials exert their primary effect on salt absorption has been the subject of considerable dispute for many years. The fact that these drugs produced a consistent reduction in $\mathrm{Tm}_{\text {glucose }}$ and $\mathrm{Tm}_{\mathrm{PAH}}$ in man suggested that these agents exerted an influence within the proximal tubule $(1,2)$. The absence of such changes in the dog, despite comparable diuretic activity, emphasized the hazards of such conclusions (3). Other experimental studies indicating that distal tubular functions such as the production of ammonia and titratable acid were not influenced by the administration of mercurials, were also used to imply a primary proximal tubular effect (4). Potassium secretion, however, which represents a late distal operation was shown to be depressed by the mercurial agents $(5,6)$. In hydrated man, it was demonstrated that meralluride produced a prompt increase in the rate of excretion of "nonsolute obligated" water implying a proximal tubular effect on salt and water absorption $(7,8)$. On the other hand, other observers reported that the administration of organomercurials to hydrated man and dog did not change the rate of free water clearance (9, 10). Recently, utilizing the stop flow technique, several investigators have concluded that, in the dog, the major site of action of the organic mercurials is confined to the proximal tubule (11, 12).

Alternatively, some investigators concluded that the distal tubule represented the site of mercurial action because the magnitude of the diuresis approximated the quantity of salt and water normally absorbed within the distal tubule (13). Others, who observed that the rate of excretion of

\footnotetext{
* Supported by a grant from the National Institute of Arthritis and Metabolic Diseases, National Institutes of Health (Grant no. A-277). Presented in abstract form at the Fifty-Second Annual Meeting of the American Society for Clinical Investigation, May, 1960.

$\dagger$ Public Health Service Research Fellow of the National Heart Institute.
}

nonsolute obligated water seemed independent of the solute diuresis, also suggested a distal site of action (14).

Recently acquired insight (15-19) suggests that subjects deficient in antidiuretic hormones $(\mathrm{ADH})$ forming maximally dilute urine, might be used to localize the site of action of an agent which alters tubular salt reabsorption. In such subjects, proximal tubular fluid remains isosmotic to plasma as the absorption of the major fraction of the filtered salt and water occurs. This absorptive process is therefore accomplished without the generation of nonsolute obligated or free water. From the tip of the loop of Henle into the collecting duct, salt is reabsorbed actively through a segment relatively impermeable to water, thereby producing free water for excretion. The available micropuncture data suggest that the major portion of this free water is formed between the tip of the loop of Henle and the beginning of the distal convolutions $(15,16)$. It is generally accepted that, as increasing quantities of salt are presented to this site, more salt may be absorbed with an increase in the excretion of free water. Contrariwise, an action inhibiting salt absorption at this site would be expected to decrease the rate of excretion of nonsolute obligated water. Whether the quantity of free water formed is appreciably reduced by the passive back diffusion of water through the impermeable distal tubule is not certain. On the basis of these considerations, it seems possible to localize the site at which an agent affects salt reabsorption by comparing the changes in the clearance of solute with those in the clearance of nonsolute obligated or free water. Accordingly, a variety of acute experiments was performed in normal, maximally hydrated man in an attempt to define more precisely the site of action of meralluride. ${ }^{1}$

\footnotetext{
1 Meralluride USP, contains $0.13 \mathrm{~g}$ of organic mercurial (equivalent to $39 \mathrm{mg}$ of inorganic mercury) and $48 \mathrm{mg}$ of theophylline per $\mathrm{ml}$.
} 


\section{MATERIALS AND METHODS}

Three separate types of studies were performed in maximally hydrated fasting males, free of renal, cardiac or vascular disease. All experimental subjects were initially hydrated by a rapid intravenous infusion of 1,000 $\mathrm{ml}$ of 3 per cent dextrose and an additional oral water load calculated to provide a total water load of $20 \mathrm{ml}$ per $\mathrm{kg}$ of body weight. This initial water load was followed by an intravenous sustaining infusion of 2.5 per cent dextrose ( $139 \mathrm{mOsm}$ per L) and 0.1 per cent sodium chloride ( $38.5 \mathrm{mOsm}$ per $\mathrm{L})$ at a constant rate of $20 \mathrm{ml}$ per minute. Additional water was given by mouth when the rate of urine flow exceeded the rate of infusion. In most of the subjects the oral load comprised but a small fraction of the total intake of water.

In the first group of experiments, two types of control studies were performed. In the first type, the technique of hydration as described above was maintained for 3 hours in four subjects. In the second type of control experiments, after the rate of urine flow, solute and free water clearance had reached a steady state, three 15-minute control periods were obtained. Thereafter, the sustaining infusion was changed to contain one of several "nonspecific solute diuretics," 2 but the rate of infusion was maintained at $20 \mathrm{ml}$ per minute. In four subjects a solution containing 3.5 per cent mannitol (196 mOsm per L), and in three subjects a solution containing 0.71 per cent sodium sulfate $(150 \mathrm{mOsm}$ per $\mathrm{L})$ and 0.15 per cent sodium bicarbonate $(34 \mathrm{mOsm}$ per $\mathrm{L})$ were substituted for the sustaining solution. In three subjects $250 \mathrm{ml}$ of an 8 per cent solution of urea was administered for 12.5 minutes; and, in three subjects 200 $\mathrm{mg}$ of aminophylline (equal to the quantity of theophylline present in $3 \mathrm{ml}$ of meralluride) was added to $200 \mathrm{ml}$ of the sustaining infusion and infused in 10 minutes. After the administration of urea or aminophylline, the original sustaining solution was reinfused at $20 \mathrm{ml}$ per minute. During the administration of these agents and for the succeeding 60 to 90 minutes, urine was collected by spontaneous voiding at 10 - to 20 -minute intervals. The subjects remained recumbent throughout the experiment except when standing to void. Blood samples were taken at infrequent intervals in an attempt to reduce the formation of endogenous $\mathrm{ADH}$. Blood and urine samples were analyzed for total solute, inulin, sodium, chloride and potassium concentrations.

2 A "nonspecific solute diuretic" is defined, for the purposes of this study, as an agent which increases the quantity of isosmotic fluid escaping proximal reabsorption. This action is effected by limiting proximal reabsorption (actively or passively) and/or by increasing glomerular filtration rate. Urea (20), sulfate (21), and mannitol (22) act as solute diuretics by passively limiting the absorption of salt and water in the proximal tubule and by sweeping more solute into the distal tubule. Theophylline seems to inhibit active proximal salt absorption and in addition may cause a transient but slight increase in glomerular filtration rate (23).
In the second group of experiments, 21 subjects were initially hydrated as described in group I. After a steady state had been achieved, $3 \mathrm{ml}$ of meralluride was administered intravenously over a period of 3 to $5 \mathrm{~min}$ utes. Thereafter, urine was collected by spontaneous voiding at 10 - to 20 -minute intervals for approximately 2.5 hours. Urine and plasma measurements, as described in the group I experiments, were performed.

In the third group of experiments, a nonspecific solute diuretic was administered to 10 of the 21 subjects from group II during the maximal phase of the merallurideinduced solute diuresis. The nonspecific solute diuretics were identical with those utilized in the second type of control study, and the technique of administration was the same as that described for this group of control experiments. Four subjects received the mannitol solution, one the sulfate solution, three the urea solution, and two the aminophylline solution.

Methods for the determination of plasma and urine osmolalities and inulin and electrolyte concentrations were similar to those previously described from this laboratory (24).

The osmolal clearance $\left(\mathrm{C}_{\mathrm{osm}}\right)$ and the clearance of free water $\left(\mathrm{C}_{\mathrm{H}_{2} \mathrm{O}}\right)$ or nonsolute obligated water clearance were calculated from the following formulas (9):

$$
\begin{aligned}
\mathrm{C}_{\text {osm }} & =\frac{\mathrm{U}_{\text {osm }} \mathrm{V}}{\mathrm{P}_{\text {osm }}} \\
\mathrm{CH}_{2} \mathrm{O} & =\mathrm{V}-\mathrm{C}_{\text {osm }}
\end{aligned}
$$

where $U_{o s m}$ represents osmolal concentration of urine, $\mathrm{P}_{\mathrm{osm}}=$ osmolal concentration of plasma, and $\mathrm{V}$ is the urine flow in milliliters per minute. Throughout the remainder of the paper the terms nonsolute obligated or free water clearance will be used interchangeably with $\mathrm{C}_{\mathrm{H}_{2} \mathrm{O}}$, and osmolal clearance with $\mathrm{C}_{\mathrm{osm}}$.

\section{RESULTS}

I. Control experiments (Table I; Figure 1). In Table I, one typical control experiment (A.L.) reveals that the hydrating technique used in these studies produced a relatively constant rate of solute and free water clearance with $\mathrm{C}_{\mathrm{H}_{2} \mathrm{O}}$ and $\mathrm{C}_{\text {osm }}$ varying less than 2 and $1 \mathrm{ml}$ per minute, respectively, for approximately 3 hours. In the second type of control study, the administration of mannitol, urea or sulfate produced a consistent increase in $\mathrm{C}_{\mathrm{H}_{2} \mathrm{O}}$ as $\mathrm{C}_{\text {osm }}$ progressively rose (Table I; Figure 1). In the four subjects receiving the mannitol solution, the increment in $\mathrm{C}_{\mathrm{H}_{2} \mathrm{O}}$ averaged $3.9 \mathrm{ml}$ per minute coincident with an average increase in $\mathrm{C}_{\text {osm }}$ of $8.1 \mathrm{ml}$ per minute. In the three subjects receiving the sulfate solution, the increase of $\mathrm{C}_{\mathrm{H}_{2} \mathrm{O}}$ averaged $5.6 \mathrm{ml}$ per minute and that in $\mathrm{C}_{\text {osm }}$ averaged $6.6 \mathrm{ml}$ per minute. The increments in $\mathrm{C}_{\mathrm{H}_{2} \mathrm{O}}$ and $\mathrm{C}_{\text {osm }}$ averaged 3.6 and $7.4 \mathrm{ml}$ per min- 
EFFECTS AND SITE OF ACTION OF MERALLURIDE IN HYDRATED MAN

TABLE I

The effect of nonspecific solute diuretics on solute and free water clearance in hydrated man *

\begin{tabular}{|c|c|c|c|c|c|}
\hline \multicolumn{6}{|c|}{ Urine solute and water excretion } \\
\hline Subject & Time & $\begin{array}{c}\text { Urine } \\
\text { osmolarity } \\
\text { (U) }\end{array}$ & $\begin{array}{c}\text { Urine } \\
\text { flow (V) }\end{array}$ & $\begin{array}{c}\text { Solute } \\
\text { clearance } \\
(\mathrm{UV} / \mathrm{P})\end{array}$ & $\begin{array}{c}\text { Free water } \\
\text { clearance } \\
\left(\mathrm{CH}_{20} \mathrm{O}\right)\end{array}$ \\
\hline & $\min$ & $m O s m / L$ & $\mathrm{ml} / \mathrm{min}$ & $m l / m i n$ & $m l / m i n$ \\
\hline \multirow[t]{2}{*}{ A.L. } & Control & 59 & 18.2 & 4.1 & 14.1 \\
\hline & $\begin{array}{c}0-18 \\
18-40 \\
40-62.5 \\
62.5-79 \\
79-99 \\
99-117.5 \\
117.5-136\end{array}$ & $\begin{array}{l}57 \\
55 \\
57 \\
53 \\
53 \\
58 \\
60\end{array}$ & $\begin{array}{l}18.8 \\
19.1 \\
20.2 \\
18.1 \\
19.2 \\
18.6 \\
19.1\end{array}$ & $\begin{array}{l}4.1 \\
4.0 \\
4.4 \\
3.7 \\
3.9 \\
4.1 \\
4.4\end{array}$ & $\begin{array}{l}14.7 \\
15.1 \\
15.8 \\
14.4 \\
15.3 \\
14.5 \\
14.7\end{array}$ \\
\hline \multirow[t]{3}{*}{ H.G. } & Control & 48 & 18.2 & 3.2 & 15.0 \\
\hline & \multicolumn{5}{|c|}{ Mannitol infusion i.v. } \\
\hline & $\begin{array}{r}0-30 \\
30-45 \\
45-61 \\
61-75 \\
75-91 \\
91-104 \\
104-120\end{array}$ & $\begin{array}{r}49 \\
57 \\
62 \\
67 \\
74 \\
93 \\
100\end{array}$ & $\begin{array}{l}19.6 \\
22.3 \\
22.5 \\
23.1 \\
24.9 \\
29.7 \\
33.5\end{array}$ & $\begin{array}{r}3.5 \\
4.6 \\
5.1 \\
5.7 \\
6.7 \\
10.1 \\
12.4\end{array}$ & $\begin{array}{l}16.1 \\
17.7 \\
17.4 \\
17.4 \\
18.2 \\
19.6 \\
21.1\end{array}$ \\
\hline \multirow[t]{3}{*}{ A.C. } & Control & 35 & 19.0 & 2.7 & 16.3 \\
\hline & \multicolumn{5}{|c|}{ Sodium sulfate infusion i.v. } \\
\hline & $\begin{array}{r}0-20 \\
20-30 \\
30-41 \\
41-52 \\
52-62\end{array}$ & $\begin{array}{l}28 \\
30 \\
40 \\
60 \\
72\end{array}$ & $\begin{array}{l}21.8 \\
22.2 \\
24.3 \\
27.7 \\
34.5\end{array}$ & $\begin{array}{l}2.3 \\
2.5 \\
4.0 \\
6.2 \\
9.3\end{array}$ & $\begin{array}{l}19.5 \\
19.7 \\
20.3 \\
21.5 \\
25.2\end{array}$ \\
\hline \multirow[t]{3}{*}{ M.L. } & Control & 30 & 14.0 & 1.5 & 12.5 \\
\hline & \multicolumn{5}{|c|}{ Urea infusion i.v. } \\
\hline & $\begin{array}{c}0-16 \\
16-26.5 \\
26.5-37 \\
37-47\end{array}$ & $\begin{array}{l}55 \\
82 \\
95 \\
96\end{array}$ & $\begin{array}{l}16.3 \\
20.5 \\
23.9 \\
24.5\end{array}$ & $\begin{array}{l}3.3 \\
6.3 \\
8.5 \\
8.9\end{array}$ & $\begin{array}{l}13.0 \\
14.2 \\
15.4 \\
15.6\end{array}$ \\
\hline \multirow[t]{3}{*}{ V.S. } & Control & 20 & 14.6 & 1.2 & 13.4 \\
\hline & \multicolumn{5}{|c|}{ Aminophylline infusion i.v. } \\
\hline & $\begin{array}{c}0-10 \\
10-28 \\
28-46.5 \\
46.5-69 \\
69-91 \\
91-115.5 \\
115.5-137 \\
137-157 \\
157-175.5\end{array}$ & $\begin{array}{l}38 \\
38 \\
37 \\
27 \\
22 \\
22 \\
22 \\
22 \\
22\end{array}$ & $\begin{array}{l}20.5 \\
17.7 \\
18.1 \\
16.5 \\
15.7 \\
15.8 \\
15.4 \\
16.1 \\
15.2\end{array}$ & $\begin{array}{l}2.9 \\
2.5 \\
2.5 \\
1.7 \\
1.3 \\
1.3 \\
1.3 \\
1.3 \\
1.2\end{array}$ & $\begin{array}{l}17.6 \\
15.2 \\
15.6 \\
14.8 \\
14.4 \\
14.5 \\
14.1 \\
14.8 \\
14.0\end{array}$ \\
\hline
\end{tabular}

* In each study, the control values represent the average of three 15 -minute control periods. Subject A.L. represents one typical control experiment demonstrating that the standard hydrating technique maintained $\mathrm{CH}_{2} \mathrm{O}$ and $\mathrm{C}_{\text {osm }}$ relatively constant for approximately 3 hours. The remaining experiments comprise one typical example of each of the nonspecific solute diuretics.

ute, respectively, in the three subjects to whom urea was administered.

The administration of aminophylline produced a prompt but transient increase in $\mathrm{C}_{\mathrm{H}_{2} \mathrm{O}}$ and $\mathrm{C}_{\text {osm }}$
(Table I; Figure 1). The maximal peak increment in $\mathrm{C}_{\mathrm{H}_{2} \mathrm{O}}$ and $\mathrm{C}_{\mathrm{osm}}$ averaged 5.8 and $2.4 \mathrm{ml}$ per minute, respectively. Within 45 to $60 \mathrm{~min}$ utes these abrupt changes had subsided. 
II. Water load; meralluride (Tables II, III; Figures 1, 2 and 3). In the 21 experiments in this group the intravenous administration of meralluride caused a two-phase response. The first phase consisted of an immediate increase in urine flow and a more modest increase in solute clearance (Table II ; Figures 1A, 2 and 3). The peak increments in $\mathrm{V}, \mathrm{C}_{\mathrm{H}_{2} \mathrm{O}}$, and $\mathrm{C}_{\mathrm{osm}}$ which occurred 15 to 30 minutes after the administration of the drug, averaged $5.9,4.4$, and $1.5 \mathrm{ml}$ per minute, respectively. Thereafter, the changes tended to subside, and within 45 to 60 minutes these parameters had returned toward control pre-injection levels.

A second, more sustained, and larger solute diuresis began approximately 60 minutes after the injection of meralluride and approached its maximum within 90 to 120 minutes (Table II; Figures $1 \mathrm{~B}, 2$ and 3 ). In 17 of the 21 subjects, this phase was characterized by a progressive and similar increase in solute clearance and urine flow so that at the point of maximum solute diuresis, the $\mathrm{C}_{\mathrm{H}_{2} \mathrm{O}}$ values were virtually identical with those observed during the pre-injection control periods. This constancy of $\mathrm{C}_{\mathrm{H}_{2} \mathrm{O}}$ obtained despite an individual variation in control $\mathrm{C}_{\mathrm{H}_{2} \mathrm{O}}$ values from 6.5 to $23.9 \mathrm{ml}$ per minute. In these 17 experiments, the coincident peak increments of $\mathrm{V}$ and $\mathrm{C}_{\mathrm{osm}}$ above control values averaged 8.9 and $9.2 \mathrm{ml}$ per minute, respectively (Table III). The similarity of these values expressed the agreement between control and final values for $\mathrm{C}_{\mathrm{H}_{2} \mathrm{O}}$. In the majority of

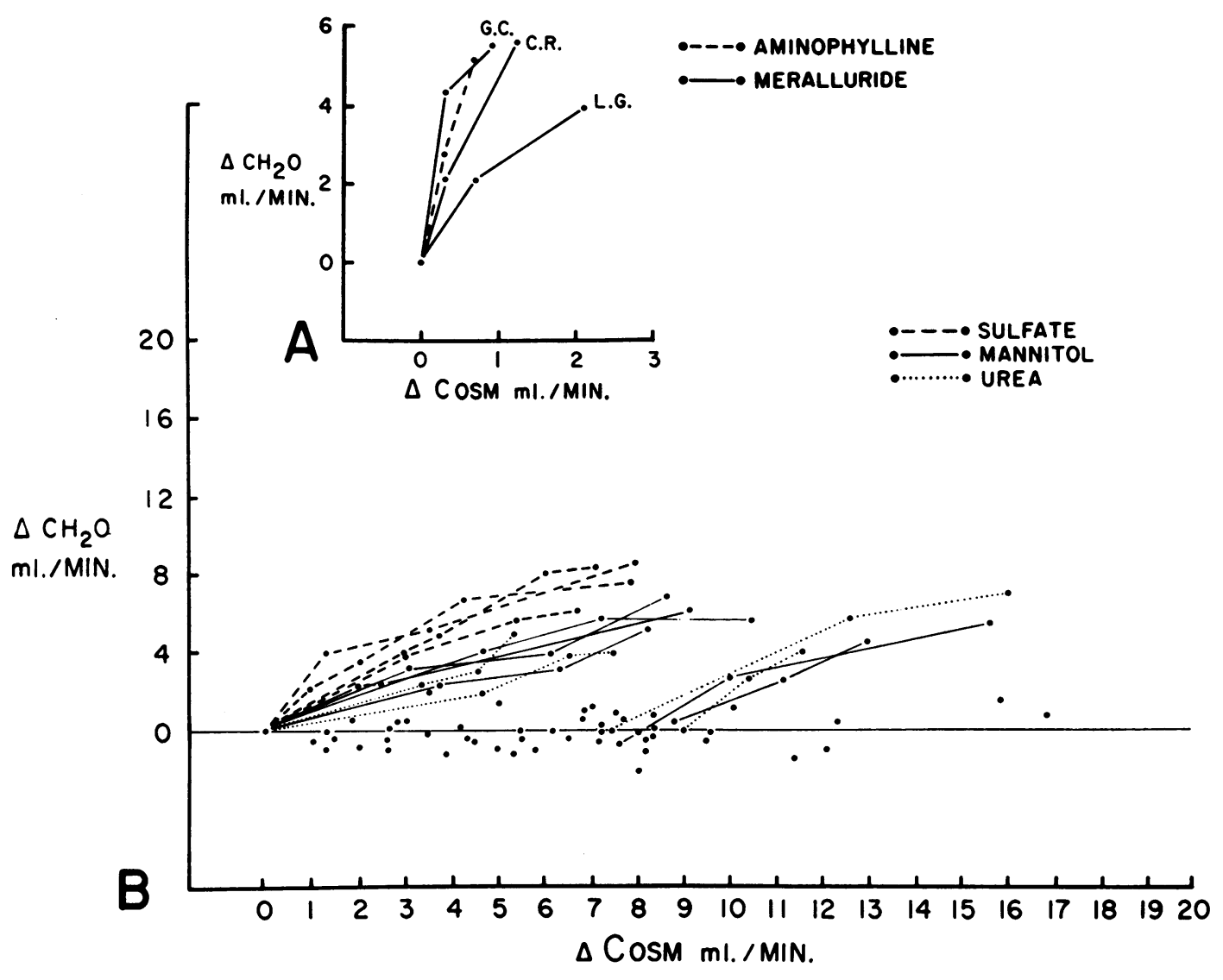

Fig. 1. A. The average change in $\mathrm{C}_{\mathrm{H}_{2} \mathrm{O}}$ and $\mathrm{C}_{\mathrm{osm}}$ produced by aminophylline compared to THAT NOTED DURING THE FIRST PHASE OF MERAlluRIDE DIURESIS IN THREE SUBJECTS. B. ThE CHANGeS

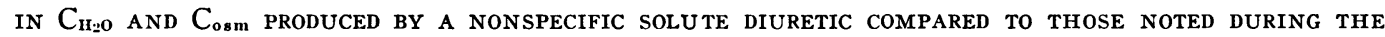
SUSTAINED PHASE OF MERALlURIDE DIURESIS. The connected points represent the changes produced by the designated nonspecific solute diuretic administered in the control state or during meralluride diuresis. The unconnected points represent the absolute difference between the premeralluride control levels and the observed values throughout the sustained phase. 
TABLE II

The effect of meralluride on solute and free water clearance in hydrated man *

\begin{tabular}{|c|c|c|c|c|c|}
\hline \multicolumn{6}{|c|}{ Urine solute and water excretion } \\
\hline Subject & Time & $\begin{array}{c}\begin{array}{c}\text { Urine } \\
\text { osmolarity } \\
\text { (U) }\end{array}\end{array}$ & $\begin{array}{c}\text { Urine } \\
\text { flow (V) }\end{array}$ & $\begin{array}{c}\text { Solute } \\
\text { clearance } \\
\text { (UV/P) }\end{array}$ & $\begin{array}{l}\text { Free water } \\
\text { clearance } \\
(\mathrm{CH} \text { 20) }\end{array}$ \\
\hline \multirow[t]{3}{*}{ C.R. } & $\begin{array}{l}\min \\
\text { Control }\end{array}$ & $\begin{array}{c}m O s m / L \\
57\end{array}$ & $\begin{array}{c}m l / m i n \\
12.3\end{array}$ & $\begin{array}{c}m l / m i n \\
2.6\end{array}$ & $\begin{array}{c}\mathrm{ml} / \mathrm{min} \\
9.7\end{array}$ \\
\hline & \multicolumn{5}{|c|}{ Meralluride i.v., $3.0 \mathrm{ml}$} \\
\hline & $\begin{array}{c}0-7 \\
14-22 \\
22-41 \\
41-58 \\
58-77.5 \\
77.5-95 \\
95-113 \\
113-130.5 \\
130.5-149 \\
149-176\end{array}$ & $\begin{array}{r}53 \\
53 \\
51 \\
92 \\
138 \\
159 \\
162 \\
160 \\
150 \\
142\end{array}$ & $\begin{array}{l}19.1 \\
14.7 \\
11.6 \\
15.8 \\
23.6 \\
29.8 \\
29.8 \\
27.9 \\
25.2 \\
24.1\end{array}$ & $\begin{array}{r}3.8 \\
2.9 \\
2.3 \\
5.6 \\
12.7 \\
18.4 \\
19.4 \\
18.0 \\
15.2 \\
13.8\end{array}$ & $\begin{array}{r}15.3 \\
11.8 \\
9.3 \\
10.2 \\
10.9 \\
11.4 \\
10.4 \\
9.9 \\
10.0 \\
10.3\end{array}$ \\
\hline \multirow[t]{3}{*}{ L.G. } & Control & 50 & 16.3 & 3.0 & 13.3 \\
\hline & \multicolumn{5}{|c|}{ Meralluride i.v., $3.0 \mathrm{ml}$} \\
\hline & $\begin{array}{c}0-14 \\
14-33 \\
33-50 \\
50-65.5 \\
65.5-79.5 \\
79.5-95.0 \\
95.0-107\end{array}$ & $\begin{array}{r}62 \\
53 \\
50 \\
65 \\
94 \\
110 \\
128\end{array}$ & $\begin{array}{l}22.4 \\
19.1 \\
17.9 \\
19.2 \\
22.1 \\
24.0 \\
26.8\end{array}$ & $\begin{array}{r}5.1 \\
3.7 \\
3.3 \\
4.6 \\
7.7 \\
9.8 \\
12.8\end{array}$ & $\begin{array}{l}17.3 \\
15.4 \\
14.6 \\
14.6 \\
14.4 \\
14.2 \\
14.0\end{array}$ \\
\hline \multirow[t]{3}{*}{ T.W. } & Control & 51 & 18.7 & 3.7 & 15.0 \\
\hline & \multicolumn{5}{|c|}{ Meralluride i.v., $3.0 \mathrm{ml}$} \\
\hline & $\begin{array}{c}0-14 \\
14-33.5 \\
33.5-52.5 \\
52.5-71.5 \\
71.5-90.5 \\
90.5-109.5 \\
109.5-129 \\
129-148 \\
148-172\end{array}$ & $\begin{array}{r}49 \\
43 \\
53 \\
91 \\
129 \\
143 \\
143 \\
141 \\
141\end{array}$ & $\begin{array}{l}22.0 \\
19.2 \\
18.0 \\
15.4 \\
21.1 \\
26.0 \\
24.8 \\
23.7 \\
23.6\end{array}$ & $\begin{array}{r}4.2 \\
3.2 \\
3.7 \\
5.6 \\
10.9 \\
14.9 \\
14.2 \\
13.4 \\
13.5\end{array}$ & \begin{tabular}{r|}
17.8 \\
16.0 \\
14.3 \\
9.8 \\
10.2 \\
11.1 \\
10.6 \\
10.3 \\
10.1
\end{tabular} \\
\hline
\end{tabular}

* In each study, the control values represent the average of three 15 -minute control periods.

these 17 experiments, the abrupt increase in $\mathrm{C}_{\mathrm{H}_{2} \mathrm{O}}$ noted during the first phase of meralluride response had disappeared before the second phase began. Thereafter, $\mathrm{C}_{\mathrm{H}_{2} \mathrm{O}}$ remained constant at control levels during the three to four periods that solute clearance and urine flow were progressively increasing.

In four experiments (Table III, Subjects J.S., A.R., E.G. and T.W.; Figure 3) the second phase of meralluride diuresis was associated with a fall in $\mathrm{C}_{\mathrm{H}_{2} \mathrm{O}}$ so that, at the peak of the solute diuresis, the calculated $\mathrm{C}_{\mathrm{H}_{2} \mathrm{O}}$ values were distinctly lower than those recorded during the pre-injection control periods. In these four subjects, the peak in- crements in $\mathrm{V}$ and $\mathrm{C}_{\mathrm{osm}}$ averaged 4.9 and $10.2 \mathrm{ml}$ per minute, respectively, accounting for the calculated fall in $\mathrm{C}_{\mathrm{H}_{2} \mathrm{O}}$. However, it appeared that in these subjects a sharp decrease in $\mathrm{C}_{\mathrm{H}_{2} \mathrm{O}}$ occurred toward the end of the first phase of meralluride diuresis, prior to the development of the major portion of the solute diuresis (Figure 3 ). Specifically, $\mathrm{C}_{\mathrm{H}_{2} \mathrm{O}}$ fell an average of $4.7 \mathrm{ml}$ per minute below control pre-injection values, while the $\mathrm{C}_{\mathrm{osm}}$ increase averaged $1.9 \mathrm{ml}$ per minute. Thereafter, as the major increase in solute excretion occurred, $\mathrm{V}$ and $\mathrm{C}_{\text {osm }}$ rose an average of 8.1 and $8.6 \mathrm{ml}$ per minute, respectively. As with the 17 subjects previously described, $\mathrm{C}_{\mathrm{H}_{2} \mathrm{O}}$ tended 
to remain fixed, albeit at levels below control values during the development of the major portion of the second phase of the solute diuresis.

The rates of sodium, chloride and potassium excretion were determined in 14 experiments. The maximal increase in the rate of sodium and chloride excretion averaged 1,250 and $1,370 \mu \mathrm{Eq}$ per minute, respectively. This increment, calculated as solute clearance of these ions, equaled 9.9 $\mathrm{ml}$ per minute, which represents 111 per cent of the mean increment in $\mathrm{C}_{\text {osm }}$ measured in these same experiments. Changes in the rate of potassium excretion during the second phase of meralluride diuresis were variable, tending to rise in six, fall in five, and remain unchanged in three experiments. In those experiments in which the rate of potassium excretion decreased, control rates averaged $61 \mu \mathrm{Eq}$ per minute and fell to 26 $\mu \mathrm{Eq}$ per minute. In the experiments in which the rate of potassium excretion increased, the control levels averaged $25 \mu \mathrm{Eq}$ per minute and rose to $57 \mu \mathrm{Eq}$ per minute. In the three experiments in which the rate of potassium excretion was unchanged, the control rates of potassium excretion were intermediate in value, averaging $35 \mu \mathrm{Eq}$ per minute. It appeared that potassium excretion decreased in those experiments in which control rates were relatively high, and the converse appeared true when the control rates of excretion were low.

TABLE III

Summary of the effect of meralluride on solute and free water clearance in hydrated man: effect of superimposed nonspecific solute diuretic*

\begin{tabular}{|c|c|c|c|c|c|c|}
\hline \multicolumn{2}{|c|}{ Subject } & \multirow{2}{*}{$\begin{array}{r}\mathrm{CH}_{2} \mathrm{O} \\
9.7 \\
10.4\end{array}$} & \multirow{2}{*}{$\begin{array}{r}\text { Cosm } \\
2.6 \\
19.4\end{array}$} & Subject & \multirow{2}{*}{$\begin{array}{l}\mathrm{CH}_{2} \mathrm{O} \\
13.1 \\
13.6 \\
17.3\end{array}$} & \multirow{2}{*}{$\begin{array}{r}\text { Cosm } \\
4.2 \\
13.0 \\
17.1\end{array}$} \\
\hline C.R. & $\begin{array}{l}1 \\
2\end{array}$ & & & $\begin{array}{rr}\text { M.L. } & 1 \\
\text { Mannitol } & 3\end{array}$ & & \\
\hline L.G. & $\begin{array}{l}1 \\
2\end{array}$ & $\begin{array}{l}13.3 \\
14.0\end{array}$ & $\begin{array}{r}3.0 \\
12.8\end{array}$ & $\begin{array}{r}\text { G.C. } \\
\text { Mannitol }\end{array}$ & $\begin{array}{l}13.5 \\
12.8 \\
17.9\end{array}$ & $\begin{array}{r}3.1 \\
10.7 \\
19.2\end{array}$ \\
\hline J.S. & $\begin{array}{l}1 \\
2\end{array}$ & $\begin{array}{l}23.9 \\
24.6\end{array}$ & $\begin{array}{r}5.6 \\
12.4\end{array}$ & $\begin{array}{rr}\text { J.T. } & 1 \\
\text { Mannitol } & 3\end{array}$ & $\begin{array}{l}12.1 \\
11.2 \\
14.2\end{array}$ & $\begin{array}{l}1.9 \\
7.7 \\
9.6\end{array}$ \\
\hline A.C. & $\begin{array}{l}1 \\
2\end{array}$ & $\begin{array}{l}10.2 \\
10.8\end{array}$ & $\begin{array}{r}2.8 \\
15.1\end{array}$ & $\begin{array}{r}\text { C.D. } \\
\text { Mannitol }\end{array}$ & $\begin{array}{l}14.6 \\
14.2 \\
17.5\end{array}$ & $\begin{array}{r}2.8 \\
10.7 \\
18.2\end{array}$ \\
\hline T.H. & $\begin{array}{l}1 \\
2\end{array}$ & $\begin{array}{l}12.1 \\
11.1\end{array}$ & $\begin{array}{r}2.8 \\
14.9\end{array}$ & $\begin{array}{r}\text { E.C. } \\
\text { Sodium sulfate }\end{array}$ & $\begin{array}{l}12.7 \\
11.1 \\
14.0\end{array}$ & $\begin{array}{r}2.7 \\
10.3 \\
12.1\end{array}$ \\
\hline F.M. & $\begin{array}{l}1 \\
2\end{array}$ & $\begin{array}{l}6.5 \\
6.4\end{array}$ & $\begin{array}{r}2.4 \\
12.0\end{array}$ & $\begin{array}{l}\text { S.G. } \\
\text { Urea }\end{array}$ & $\begin{array}{l}16.7 \\
16.7 \\
20.1\end{array}$ & $\begin{array}{r}4.6 \\
13.6 \\
16.2\end{array}$ \\
\hline J.P. & $\begin{array}{l}1 \\
2\end{array}$ & $\begin{array}{l}15.2 \\
16.2\end{array}$ & $\begin{array}{r}3.7 \\
11.2\end{array}$ & $\begin{array}{l}\text { E.D. } \\
\text { Urea }\end{array}$ & $\begin{array}{l}11.8 \\
11.4 \\
17.3\end{array}$ & $\begin{array}{r}3.9 \\
8.2 \\
17.9\end{array}$ \\
\hline E.Z. & $\begin{array}{l}1 \\
2\end{array}$ & $\begin{array}{l}13.2 \\
12.7\end{array}$ & $\begin{array}{r}3.3 \\
10.6\end{array}$ & $\begin{array}{cc}\text { J.S. } & 1 \\
\text { Urea } & 3\end{array}$ & $\begin{array}{l}18.0 \\
15.5 \\
15.7\end{array}$ & $\begin{array}{r}3.7 \\
10.7 \\
13.2\end{array}$ \\
\hline E.O. & $\begin{array}{l}1 \\
2\end{array}$ & $\begin{array}{r}10.5 \\
8.9\end{array}$ & $\begin{array}{r}2.7 \\
13.5\end{array}$ & $\begin{array}{r}\text { A.R. } \\
\text { Aminophylline }\end{array}$ & $\begin{array}{r}12.2 \\
6.3 \\
7.2\end{array}$ & $\begin{array}{r}2.5 \\
14.2 \\
15.4\end{array}$ \\
\hline T.W. & $\begin{array}{l}1 \\
2\end{array}$ & $\begin{array}{l}15.0 \\
11.1\end{array}$ & $\begin{array}{r}3.7 \\
14.9\end{array}$ & $\begin{array}{r}\text { E.G. } \\
\text { Aminophylline }\end{array}$ & $\begin{array}{r}13.8 \\
8.6 \\
9.9\end{array}$ & $\begin{array}{r}2.4 \\
14.4 \\
22.4\end{array}$ \\
\hline
\end{tabular}

* 1 represents the average of three control periods; 2 represents the $\mathrm{C}_{2} \mathrm{O}$ and $\mathrm{C}_{\mathrm{osm}}$ during the maximum sustained meralluride diuresis; and 3 represents the effect on $\mathrm{CH}_{2} \mathrm{O}$ and $\mathrm{C}_{\mathrm{osm}}$ of a superimposed nonspecific solute diuretic during sustained meralluride diuresis. 
Glomerular filtration rate was determined in 15 of the 21 experiments in group II. No consistent changes occurred as a result of meralluride administration. Throughout all these studies, there occurred a consistent and progressive diminution in serum osmolality, so that at the end of the experiments the serum osmolality averaged 13 mOsm per $L$ less than control values. A comparable diminution in serum osmolality occurred in those four experiments in which $\mathrm{C}_{\mathrm{H}_{2} \mathrm{O}}$ fell coincident with the development of the sustained meralluride-induced solute diuresis.

III. Water load; meralluride with superimposed nonspecific solute diuretics (Table IV; Figures

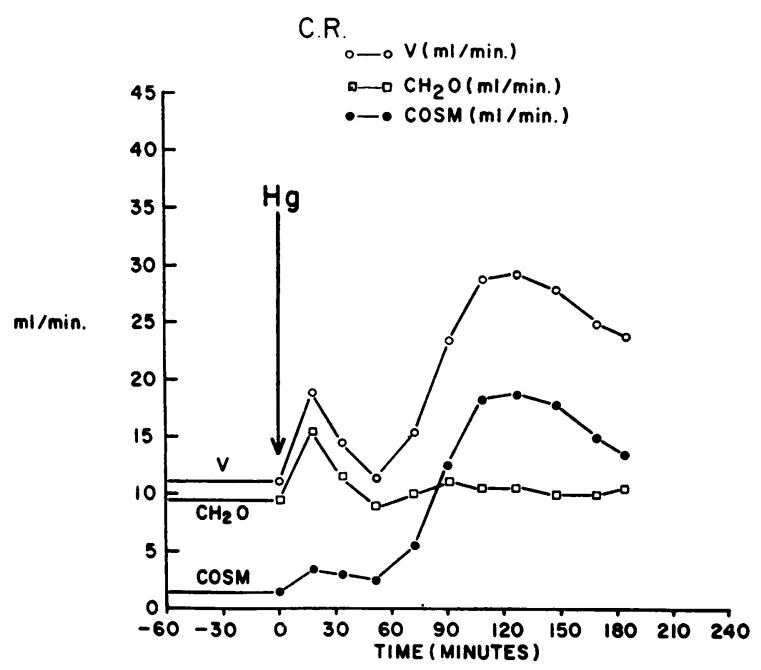

Fig. 2. EfFect of meralluride on V, $\mathrm{C}_{\mathrm{H}_{2} \mathrm{O}}$ and $\mathrm{C}_{\text {osm }}$ IN HYDRATED SUBJECT C.R. This experiment is typical of the majority of subjects in whom $\mathrm{C}_{\mathrm{H}_{2} \mathrm{O}}$ remained at control pre-injection levels during the sustained meralluride diuresis.

$1 B$ and 4$).$ In 10 of the 21 experiments described in section II above, a nonspecific solute diuretic was administered during the sustained phase of meralluride diuresis, after solute clearance had increased markedly and $\mathrm{C}_{\mathrm{H}_{2} \mathrm{O}}$ was stabilized at or below pre-injection control levels. In seven of these ten studies, an increase in $\mathrm{C}_{\text {osm }}$ averaging $5.2 \mathrm{ml}$ per minute produced an increase in $\mathrm{C}_{\mathrm{H}_{2} \mathrm{O}}$ averaging $3.9 \mathrm{ml}$ per minute (2.9 to $5.9 \mathrm{ml}$ per minute). The further increase in $\mathrm{C}_{\text {osm }}$ in these seven experiments represented 67 per cent of the mean increment noted during the sustained phase of the meralluride saluresis. In three experiments, the administration of the nonspecific solute diuretics

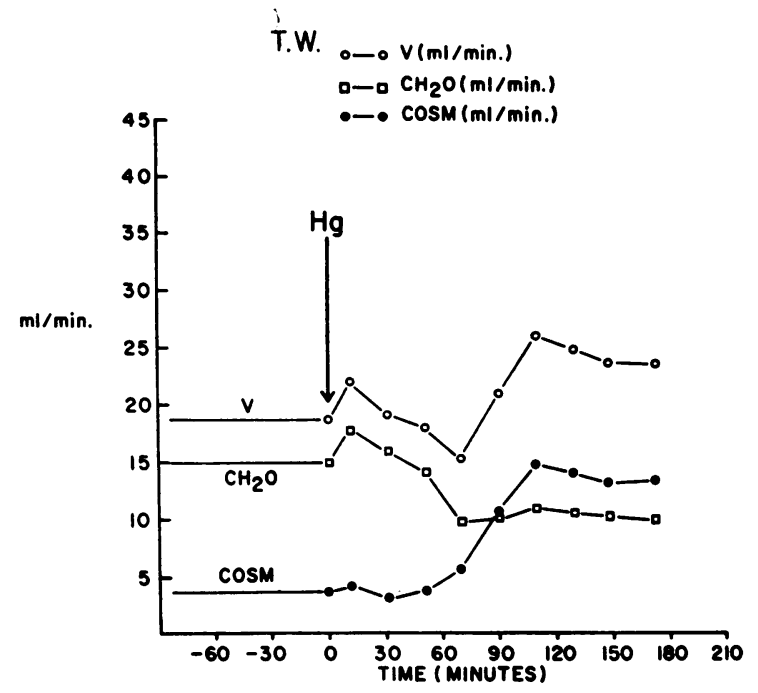

Fig. 3. Effect of meralluride on V, C $\mathrm{H}_{20}$ and $\mathrm{C}_{\text {osm }}$ IN HYDRATED SUBJECT T.W. This experiment is typical of the few subjects in whom $\mathrm{C}_{\mathrm{H}_{2} \mathrm{O}}$ fell below control preinjection levels prior to the development of the major portion of the solute diuresis.

did not produce a distinct increase in $\mathrm{C}_{\mathrm{H}_{2} \mathrm{O}}$. In these three subjects (J.S., A.R. and E.G.) $\mathrm{C}_{\mathrm{H}_{2} \mathrm{O}}$ had fallen below pre-injection control levels before the major portion of the meralluride diuresis occurred.

\section{DISCUSSION}

These experiments help to explain why some observers have noted a consistent increase in $\mathrm{C}_{\mathrm{H}_{2} \mathrm{O}}$
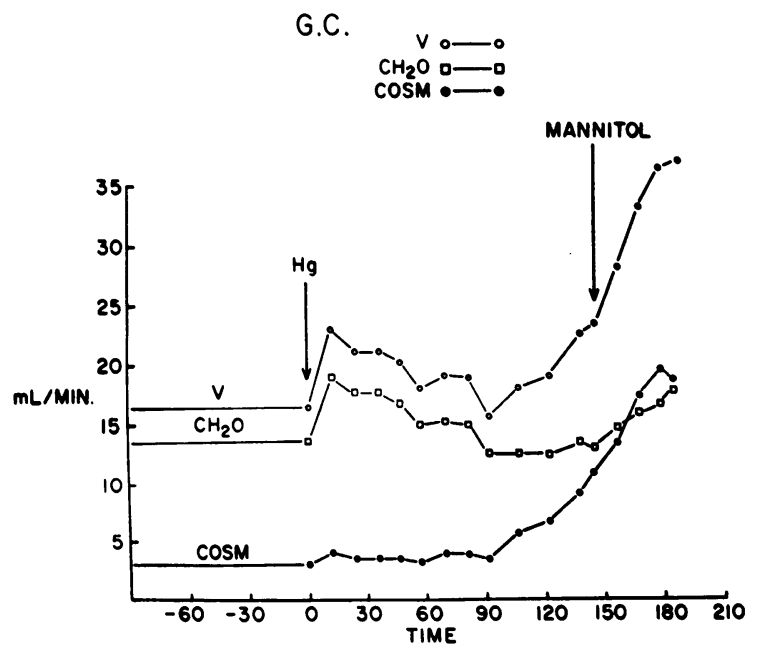

Fig. 4. Effect of meralluride on V, C $\mathrm{C}_{2} \mathrm{O}$ and $\mathrm{C}_{\text {osm }}$ IN HYDRATED SUBJECT G.C.- EFFECT OF A SUPERIMPOSED NONSPECIFIC SOLUTE DIURETIC. At the second arrow, the nonspecific solute diuretic was administered. 
TABLE IV

The effect of a superimposed nonspecific solute diuretic during sustained meralluride diuresis *

\begin{tabular}{|c|c|c|c|c|c|}
\hline \multicolumn{6}{|c|}{ Urine solute and water excretion } \\
\hline Subject & Time & $\begin{array}{c}\begin{array}{c}\text { Urine } \\
\text { osmolarity } \\
\text { (U) }\end{array} \\
\text { (u) }\end{array}$ & $\begin{array}{l}\text { Urine } \\
\text { flow (V) }\end{array}$ & $\begin{array}{c}\text { Solute } \\
\text { clearance } \\
\text { (UV/P) }\end{array}$ & $\begin{array}{l}\text { Free water } \\
\text { clearance } \\
\left(\mathrm{CH}_{2} \mathrm{O}\right)\end{array}$ \\
\hline \multirow{6}{*}{ M.L. } & $\min$ & $m O s m / L$ & $m l / m i n$ & $\mathrm{ml} / \mathrm{min}$ & $\mathrm{ml} / \mathrm{min}$ \\
\hline & Control & 69 & 17.3 & 4.2 & 13.1 \\
\hline & \multicolumn{5}{|c|}{ Meralluride i.v., $3.0 \mathrm{ml}$} \\
\hline & $\begin{array}{c}0-8.5 \\
86-101 \\
101-115.5 \\
115.5-126.5 \\
126.5-137.5 \\
137.5-147.5\end{array}$ & $\begin{array}{r}57 \\
138 \\
137 \\
132 \\
127 \\
124\end{array}$ & $\begin{array}{l}19.4 \\
24.5 \\
26.6 \\
26.5 \\
25.6 \\
25.8\end{array}$ & $\begin{array}{r}3.9 \\
12.1 \\
13.0 \\
12.5 \\
11.7 \\
11.5\end{array}$ & $\begin{array}{l}15.5 \\
12.3 \\
13.6 \\
14.0 \\
13.9 \\
14.3\end{array}$ \\
\hline & 150 & \multicolumn{3}{|c|}{ Mannitol infusion i.v. } & \\
\hline & $\begin{array}{r}150-158.5 \\
158.5-169.5 \\
180-189.5 \\
189.5-197\end{array}$ & $\begin{array}{l}123 \\
137 \\
140 \\
138\end{array}$ & $\begin{array}{l}26.1 \\
30.9 \\
33.8 \\
34.4\end{array}$ & $\begin{array}{l}11.5 \\
15.2 \\
17.0 \\
17.1\end{array}$ & $\begin{array}{l}14.6 \\
15.7 \\
16.8 \\
17.3\end{array}$ \\
\hline \multirow[t]{5}{*}{ G.C. } & Control & 52 & 16.6 & 3.1 & 13.5 \\
\hline & \multicolumn{5}{|c|}{ Meralluride i.v., $3.0 \mathrm{ml}$} \\
\hline & $\begin{array}{c}0-15 \\
15-26.5 \\
26.5-37 \\
37-47 \\
57-67 \\
67-79 \\
79-90 \\
90-100.5 \\
100.5-114.5 \\
114.5-130 \\
130-146 \\
146-152\end{array}$ & $\begin{array}{r}49 \\
45 \\
48 \\
48 \\
48 \\
54 \\
57 \\
62 \\
85 \\
97 \\
109 \\
122\end{array}$ & $\begin{array}{l}23.0 \\
21.2 \\
20.5 \\
20.2 \\
18.2 \\
19.2 \\
19.1 \\
15.8 \\
18.2 \\
19.2 \\
22.8 \\
23.5\end{array}$ & $\begin{array}{r}4.0 \\
3.4 \\
3.6 \\
3.5 \\
3.2 \\
3.8 \\
4.0 \\
3.6 \\
5.7 \\
6.9 \\
9.2 \\
10.7\end{array}$ & $\begin{array}{l}19.0 \\
17.8 \\
16.9 \\
16.7 \\
15.0 \\
15.4 \\
15.1 \\
12.2 \\
12.5 \\
12.3 \\
13.6 \\
12.8\end{array}$ \\
\hline & 153 & \multicolumn{3}{|c|}{ Mannitol infusion i.v. } & \\
\hline & $\begin{array}{l}153-163 \\
163-173 \\
173-183 \\
183-191\end{array}$ & $\begin{array}{l}129 \\
140 \\
143 \\
137\end{array}$ & $\begin{array}{l}28.2 \\
32.2 \\
36.4 \\
37.1\end{array}$ & $\begin{array}{l}13.6 \\
17.4 \\
19.6 \\
19.2\end{array}$ & $\begin{array}{l}14.6 \\
15.8 \\
16.8 \\
17.9\end{array}$ \\
\hline
\end{tabular}

* These studies represent the results in two typical experiments. In each study, the control values represent the average of three 15 -minute control periods.

after the administration of meralluride in man $(7,8)$. The prompt increase in free water clearance appears to be transient in nature and is associated with a modest solute diuresis. The subsequent, more sustained and greater solute diuresis occurs predominantly without an increase in $\mathrm{C}_{\mathrm{H}_{2} \mathrm{O}}$. The specific changes observed in free water clearance will therefore depend on whether the early or delayed phase of meralluride response is subjected to analysis.

The similarity between the immediate response to the administration of meralluride and that produced by an equal quantity of aminophylline suggests that the first phase of meralluride diuresis represents a theophylline effect (Tables I and II; Figure 1). Prompt increases in the rate of salt and water excretion have been described after the intravenous administration of xanthine diuretics in man $(23,25)$. Assuming that theophylline produces an abrupt but transient increase in the quantity of isosmotic fluid escaping proximal tubular reabsorption, $\mathrm{C}_{\mathrm{H}_{2} \mathrm{O}}$ would be expected to rise as a major fraction of this additional solute load is absorbed in the early distal tubule. Similar experiments performed in this laboratory with nontheophylline-containing mercurials do not reveal this transient first phase (26).

The second phase of meralluride diuresis is 
characterized by a relatively constant $\mathrm{C}_{\mathrm{H}_{2} \mathrm{O}}$ at or, less frequently, below control levels during the development of a more pronounced solute diuresis (Tables II-IV; Figures 1-4). It does not appear that this sustained saluresis can be explained by a primary proximal tubular action of meralluride. In the control studies presented here (Table I; Figure 1), the infusion of mannitol, sodium sulfate, urea and aminophylline has consistently increased $\mathrm{C}_{\mathrm{H}_{2} \mathrm{O}}$ as $\mathrm{C}_{\text {osm }}$ rises through a range comparable to that observed during the second phase of meralluride diuresis. Micropuncture studies have also demonstrated the capacity of the distal tubule to absorb considerable quantities of an additional load (16).

Nor can the sustained phase of meralluride diuresis be attributed to an action primarily at the water-clearing segment of the distal tubule. The inhibition of salt absorption at this site would be expected to reduce $\mathrm{C}_{\mathrm{H}_{2} \mathrm{O}}$ as the solute clearance increased. This fall in $\mathrm{C}_{\mathrm{H}_{2} \mathrm{O}}$ might be partially obscured by the more distal absorption of a fraction of this excess salt or by the influence of the increased salt concentration in diminishing subsequent back diffusion of water (27). However, it is likely that as salt excretion increased, some relation between the changes in $\mathrm{C}_{\text {osm }}$ and $\mathrm{C}_{\mathrm{H}_{2} \mathrm{O}}$ would obtain. No such relation was observed in these studies. It seems warranted, therefore, to conclude that the sustained phase of meralluride diuresis may not be attributed to a major action solely at the proximal tubule or at the waterclearing segment of the distal tubule.

The characteristics of the delayed phase of meralluride diuresis could be explained by a balance of depressive effects on salt absorption in the proximal tubule and in the water-clearing site of the distal tubule. Specifically, meralluride would limit salt absorption at the latter site to approximately that rate in operation during the control period. The simultaneous inhibition of proximal salt and water absorption would then permit the rejected isosmotic fluid to pass through the distal tubule as if the latter were an inactive conduit. Although such a balance of effects would explain much of the observed data in which $\mathrm{C}_{\mathrm{H}_{2} \mathrm{O}}$ remained at control levels as solute excretion rose, this hypothesis is difficult to defend. If the major portion of the saluresis is derived from the proximal tubule, the salt concentration of the fluid reaching most of the distal tubule would rise progressively. It would be anticipated that a variable fraction of this additional load would be absorbed distally, thereby increasing $\mathrm{C}_{\mathrm{H}_{2} \mathrm{O}}$. In addition, a rise in distal tubular salt concentration would be expected to limit back diffusion of water (27), also tending to increase $\mathrm{C}_{\mathrm{H}_{2} \mathrm{O}}$. In support of these predictions is the observation that during this phase of meralluride diuresis, the administration of a nonspecific solute diuretic usually augmented $\mathrm{C}_{\mathrm{H}_{2} \mathrm{O}}$ (Tables III and IV; Figure 4).

Finally, it is conceivable that a progressively greater inhibition of salt absorption at the waterclearing site coincident with proximal inhibition would counterbalance the factors tending to increase $\mathrm{C}_{\mathrm{H}_{2} \mathrm{O}}$ later in the distal tubule. This hypothesis would demand that two opposite effects consistently neutralize each other's influence on $\mathrm{C}_{\mathrm{H}_{2} \mathrm{O}}$ at varying rates of solute excretion.

Therefore, the possibility that the sustained phase of meralluride diuresis is explicable by a balance of proximal and distal effects, while not excluded, presents serious limitations. It seems in order to consider an alternate explanation for these findings.

The relative independence of $\mathrm{C}_{\mathrm{H}_{2} \mathrm{O}}$ during the development of the meralluride-induced saluresis suggests that this agent may alter the rate of tubular salt and water reabsorption at a site distal to the water-clearing segment of the distal tubule. Such a hypothesis would explain the relative constancy of the $\mathrm{C}_{\mathrm{H}_{2} \mathrm{O}}$ regardless of its precise level at the onset of the diuresis, since free water would be generated proximal to the major site of meralluride action. This hypothesis would be consistent with the rise in $\mathrm{C}_{\mathrm{H}_{2} \mathrm{O}}$ observed when nonspecific solute diuretics sweep more absorbable solute into the water-clearing segment of the distal tubule. In the several experiments in which $\mathrm{C}_{\mathrm{H}_{2} \mathrm{O}}$ fell below control levels prior to the onset of the major fraction of the salt diuresis (Table II; Figure 3), an additional earlier modest restriction on salt absorption in the water-clearing site would be implied. $^{3}$

\footnotetext{
3 It is conceivable that this fall in $\mathrm{C}_{\mathrm{H}_{2} \mathrm{O}}$ which preceded the major solute diuresis was caused by the formation of endogenous $\mathrm{ADH}$. However, the relative constancy of the $\mathrm{C}_{\mathrm{H}_{2} \mathrm{O}}$ thereafter and the falling serum osmolalities argue against an $\mathrm{ADH}$ effect. If such a fall in $\mathrm{C}_{\mathrm{H}: \mathrm{O}}$ were due to the formation of some $\mathrm{ADH}$ and the sub-
} 
This alternate explanation of the meralluride diuresis also presents serious problems. The similarity between the increment in $\mathrm{C}_{\text {osm }}$ and $\mathrm{V}$ during the development of this diuresis (relative constancy of $\mathrm{C}_{\mathrm{H}_{2} \mathrm{O}}$ ) would demand that salt and water be absorbed in approximately isosmotic proportions at this late distal site, despite the absence of $\mathrm{ADH}$. Micropuncture studies suggest that the segment of the distal tubule least permeable to water extends from the tip of the ascending loop of Henle to the beginning of the distal convoluted tubule $(15,16,28)$. It is probable that this is the segment of the distal tubule in which free water is formed. The proposed site of isosmotic salt and water absorption would then have to be beyond the beginning of the distal convoluted tubule.

Micropuncture data in hydrated animals which might be used to support or negate this hypothesis are sparse. Those which are available show that tubular fluid tonicity promptly falls to half that of plasma in the early distal tubule (15). It remains at that level until, at a more distal area, tubular fluid tonicity again falls progressively, approaching the ultimate concentration of urine or approximately one-fourth that of plasma (15). While it has been assumed that this further dilution is due to the continued extraction of salt at a water-impermeable segment, a comparable degree of dilution could be reached by extracting isosmotic fluid from a dilute tubular fluid. It is difficult to envision a process by which salt and water are absorbed late in the distal tubule in approximately isosmotic proportions from a variably dilute parent fluid. The only isosmotic absorptive process thus far demonstrated by micropuncture has been localized within the proximal segment. In this instance, the fluid from which absorption takes place is likewise isosmotic. Net movement of water is assumed to be dependent upon osmotic gradients established by active transport of solute across a freely permeable membrane. Were such a membrane present distal to the site at which free water is formed, it would be difficult to explain the persistent hypotonicity of the urine. Therefore, the hypothetical process suggested here

sequent solute diuresis did not enhance $\mathrm{C}_{\mathrm{H}_{2} \mathrm{O}}$ (27), these observations would also suggest that the solute diuresis derived from a site distal to the water-clearing segment. would have to feature a constant relation between the quantity of salt and water absorbed per unit time regardless of the intratubular salt concentration. Although some correlation between solute and water absorption has been observed in the gastrointestinal tract, frog skin and toad bladder (29-32), the exact relation remains to be elucidated.

On the basis of stop flow experiments in the dog, it has been reported that the primary action of the organomercurials is localized in the proximal tubule $(11,12)$. However, the use of this method to evaluate proximal changes is subject to considerable doubt. The alleged proximal effect may be due to the subsequent influence of altered distal tubular function as the proximal fluid passes this latter site when flow is resumed. A reduction in distal tubular activity might be obscured by the prolonged contact between the distal tubular fluid and the adjacent tubular wall. Furthermore, as with other mercurial effects, it is possible that a species difference exists in the site of inhibition of salt absorption between man and dog.

In summary, two alternate hypotheses are presented to explain the delayed phase of the meralluride diuresis. One demands a unique balance of proximal and distal tubular effects. The other places the major action in a segment distal to the water-clearing site, assuming that salt and water are absorbed in relatively isosmotic proportions at this segment. Although the latter hypothesis explains the observed facts more completely, it demands the existence of a process which has not been demonstrated.

\section{SUMMARY}

1. In control studies in hydrated subjects it was demonstrated that the infusion of a "nonspecific solute diuretic," such as mannitol, sulfate, urea or aminophylline produced a consistent increase in $\mathrm{C}_{\mathrm{H}_{2} \mathrm{O}}$ as $\mathrm{C}_{\text {osm }}$ rose.

2. In 21 comparably hydrated subjects, the intravenous administration of meralluride caused a two-phase response. The first phase was characterized by a prompt increase in $\mathrm{V}, \mathrm{C}_{\mathrm{H}_{2} \mathrm{O}}$ and $\mathrm{C}_{\mathrm{osm}}$ with peak increments averaging 5.9, 4.4 and 1.5 $\mathrm{ml}$ per minute, respectively. These changes tended to disappear within 45 to 60 minutes. Thereafter, 
there occurred a much larger and more sustained diuresis. In 17 of these subjects, the peak increments in $\mathrm{V}$ and $\mathrm{C}_{\text {osm }}$ averaged 8.9 and $9.2 \mathrm{ml}$ per minute, respectively, so that $\mathrm{C}_{\mathrm{H}_{2} \mathrm{O}}$ values during this maximal diuresis were virtually identical with those calculated during the pre-injection control periods. In four of these subjects, $\mathrm{C}_{\mathrm{H}_{2} \mathrm{O}}$ fell to levels below control values immediately prior to the development of the major portion of the solute diuresis, but again remained relatively fixed during the saluresis.

3. In 10 of the 21 subjects described above, a nonspecific solute diuretic was administered during the delayed phase of meralluride diuresis. In seven of these experiments, a further increase in $\mathrm{C}_{\text {osm }}$, averaging $5.2 \mathrm{ml}$ per minute, produced an average increase in $\mathrm{C}_{\mathrm{H}_{2} \mathrm{O}}$ of $3.9 \mathrm{ml}$ per minute.

4. The first phase of meralluride response seems best explained by the theophylline contained within meralluride. Two alternate hypotheses are presented to explain the characteristics of the sustained phase of meralluride diuresis.

\section{REFERENCES}

1. Weston, R. E., Grossman, J., Edelman, I. S., Escher, D. J. W., Leiter, L., and Hellman, L. Renal tubular action of diuretics. II. Effects of mercurial diuresis on glucose reabsorption. Fed. Proc. 1949, 8, 164.

2. Brun, C., Hilden, T., and Raaschou, F. On the effects of mersalyl on renal function. Acta pharmacol. (Kbh.) 1947, 3, 1.

3. Berliner, R. W., Kennedy, T. J., Jr., and Hilton, J. G. Salyrgan and renal tubular secretion of para-aminohippurate in the dog and man. Amer. J. Physiol. 1948, 154, 537.

4. Weston, R. E., Grossman, J., and Leiter, L. The effect of mercurial diuretics on renal ammonia and titratable acidity production in acidotic human subjects with reference to site of diuretic action. J. clin. Invest. 1951, 30, 1262.

5. Mudge, G. H., Ames, A., III, Foulks, J., and Gilman, A. Effects of drugs on renal secretion of potassium in the dog. Amer. J. Physiol. 1950, 161, 151.

6. Berliner, R. W., Kennedy, T. J., Jr., and Hilton, J. G. Renal mechanisms for excretion of potassium. Amer. J. Physiol. 1950, 162, 348.

7. Heinemann, H. O., and Becker, E. L. Effect of a mercurial diuretic on the excretion of free water in diabetes insipidus. J. appl. Physiol. 1958, 12, 51.

8. Heinemann, H. O., Demartini, F. E., and Laragh, J. H. The effect of chlorothiazide on renal excretion of electrolytes and free water. Amer. J. Med. 1959, 26, 853.
9. Wesson, L. G., Jr., and Anslow, W. P., Jr. Effect of osmotic and mercurial diuresis on simultaneous water diuresis. Amer. J. Physiol. 1952, 170, 255.

10. Capps, J. N., Wiggins, W. S., Axelrod, D. R., and Pitts, R. F. The effect of mercurial diuretics on the excretion of water. Circulation 1952, 6, 82.

11. Kessler, R. H., Hierholzer, K., Gurd, R. S., and Pitts, R. F. Localization of diuretic action of chlormerodin in the nephron of the dog. Amer. J. Physiol. 1958, 194, 540.

12. Vander, A. J., Malvin, R. L., Wilde, W. S., and Sullivan, L. P. Localization of the site of action of mercurial diuretics by stop flow analysis. Amer. J. Physiol. 1958, 195, 558.

13. Duggan, J. J., and Pitts, R. F. Studies on diuretics. I. The site of action of mercurial diuretics. J. clin. Invest. 1950, 29, 365.

14. Dale, R. A., and Sanderson, P. H. The mode of action of a mercurial diuretic in man. J. clin. Invest. $1954,33,1008$.

15. Wirz, $H$. The localization of antidiuretic action in the mammalian kidney in The Neurohypophysis. New York, Academic Press, 1957, p. 157.

16. Gottschalk, C. W., and Mylle, M. Micropuncture study of the mammalian urinary concentrating mechanism: Evidence for the countercurrent hypothesis. Amer. J. Physiol. 1959, 196, 927.

17. Walker, A. M., Bott, P. A., Oliver, J., and MacDowell, M. C. The collection and analysis of fluid from single nephrons of the mammalian kidney. Amer. J. Physiol. 1941, 134, 580.

18. Smith, H. W. Renal excretion of sodium and water. Fed. Proc. 1952, 11, 701.

19. Berliner, R. W., Levinsky, N. G., Davidson, D. G., and Eden, $M$. Dilution and concentration of the urine and the action of anti-diuretic hormone. Amer. J. Med. 1958, 24, 730.

20. Mudge, G. H., Foulks, J., and Gilman, A. Effect of urea diuresis on renal excretion of electrolytes. Amer. J. Physiol. 1949, 158, 218.

21. Shannon, J. A. Urea excretion in the normal dog during forced diuresis. Amer. J. Physiol. 1938, 122,782

22. Wesson, L. G., Jr., and Anslow, W. P., Jr. Excretion of sodium and water during osmotic diuresis in the dog. Amer. J. Physiol. 1948, 153, 465.

23. Davis, J. W., and Shock, N. The effect of theophylline ethylene-diamine on renal function in control subjects and in patients in congestive failure. J. clin. Invest. 1949, 28, 1459.

24. Levitt, M. F., Levy, M. S., and Polimeros, D. The effect of a fall in filtration rate on solute and water excretion in hydropenic man. J. clin. Invest. 1959, 38, 463.

25. Green, D. M., Bridges, W. C., Johnson, A. D., Lehmann, J. H., Gray, F., and Field, L. Xanthine studies: 2) Effect of aminophylline, 1,3 diethyl 8 bromoxanthine and 1,3 dimethyl 8 chloroxanthine 
on water and sodium excretion. Fed. Proc. 1949, 8, 296.

26. Goldstein, M. H., Levitt, M. F., and Hauser, A. D. Unpublished observations.

27. Orloff, J., Wagner, H. N., Jr., and Davidon, D. G. The effect of variations in solute excretion and vasopressin dosage on the excretion of water in the dog. J. clin. Invest. 1958, 37, 458.

28. Ullrich, K. J., and Jarausch, K. H. Untersuchungen zum Problem der Harnkonzentrierung und Harnverdünnung. Pflüg. Arch. ges. Physiol. 1956, 262, 537.

29. Visscher, M. B., Fetcher, E. S., Jr., Carr, C. W., Gregor, H. P., Bushey, M. S., and Barker, D. E.
Isotopic tracer studies on the movement of water and ions between intestinal lumen and blood. Amer. J. Physiol. 1944, 142, 550.

30. Ussing, H. H. Active transport of inorganic ions in Symposia of the Society for Experimental Biology, VIII, Active Transport and Secretion. New York, Academic Press, 1954, p. 407.

31. Leaf, A., Anderson, J., and Page, L. B. Active sodium transport by the isolated toad bladder. $\mathrm{J}$. gen. Physiol. 1958, 41, 657.

32. Vaughan, B. E. Intestinal electrolyte absorption by parallel determination of unidirectional sodium and water transfers. Amer. J. Physiol. 1960, 198, 1235. 